\title{
Budgeting In Australia: Lessons for Nigeria
}

\author{
Agu,Sylvia Uchenna \\ Department of Public Administration and Local Government, University of Nigeria, Nsukka.
}

\begin{abstract}
This paper is on Budget and Economic Transformation in Australia: lessons for Nigeria. It brings to the fore the nagging issue of poor budget process in Nigeria. The paper reiterates the importance of good budget as an instrument for economic transformation. Unfortunately, Nigerian budget process is very poor and extant laws have not addressed this important fiscal challenge. The paper identifies the lapses in the Nigerian budget process which made budget implementation ineffective and concludes by proffering a successful country's budget process (Australia) that Nigeria could emulate to correct the identified lapses.
\end{abstract}

Keywords: Budget Process, Institutional Reform, Transformation, Gross Domestic Product and Net Debt

\section{Introduction}

Budgeting is one of the most important areas of policymaking. Budgeting serves as an essential element of planning and controlling a country's limited resources and subsequently provides a guide for management decisions in adjusting plans and objectives if there is an uncontrollable change in condition. Through budgets, governments indicate how much it is willing to spend on public purposes, set substantive policy priorities within overall spending levels, determine the amount that must be borrowed in order to finance approved spending levels, and thus influence the economy (Kutt 2008, Su 2007,Blondal et al 2008,Bland 2008, Groenewegen 2008 Dirk et al 2012, Nai 2012, and Wan et al 2012, Ekeocha, 2012). A good budget helps a country from getting into debt and also promotes employment.

Our major focus is on government budget that looks at the estimation of the proposed expenditures for specified purposes and periods and embodies the means for controlling the estimated amounts to be raised as well as the amounts to be spent for specified periods, and it will be limited to budget operations in normal times, for it is obvious that wartime budgets introduce new principles both in regard to spending and in accounting methods. However, both in the authoritarian and democratic society, the budget is a vital link in the system of controlling the government. In any of the systems, it is a means whereby the government influences social policy, moulds the economic structures, and achieves its political aims. (Bland 2008, Agu, 2000,Brethon 1975, Wildavsky 1984, Rubin 1990,Brunce et al 1995, Kluver 2001, and scheers et al 2005) Budgeting advocates argue that resources available are not always sufficient to service the needs/opportunities which the country would like to render; also budgeting emphasizes on the relevance of the projects to be undertaken aimed at developing the country. A good budget must of necessity be simple, timely, measurable, comprehensible reasonable and achievable( Okolo 2012).

However, since independence in 1960, the various administrations in Nigeria have exhibited consciousness of the need to animate Nigeria's development and have tried to achieve these through the formulation of appropriate policies. Much of these efforts were through the broad strategy of designing Five Year National Development Plans (NDPs), of which there have been four, and two Rolling Plans. These NDPs did not only spell out objectives but also contained specific strategies for their actualisation. Therefore, between 1960 and 1985, Nigeria had four national development plans aimed at the development of the country. The failure of this development plans to achieve its objectives led Obasanjo, the former president into resuscitating the economic process of deregulation and liberalisation which had its origin in Structural Adjustment Programme through NEEDS strategy (Ajimobi 2013, Komsla 2007).It should be noted that budgetary system is an effective device for planning, reviewing and controlling government operations, particularly in relation to the implementation of national development plan within the scope of public debt (Komsla 2007, Olufidipe, 2007, Igbuzor, 2009; Abba 2007, Kwanashie 2003 and Meyers, 1999)).Unfortunately budgeting system failed to achieve this purpose in Nigeria. This manifested in declining capacity utilisation, closure of industries, hyperinflation, rising unemployment, poverty with attendant increase in crime, and other social vices such as cultism among students. It is argued that the degree of responsiveness to the economy and the extent to which there is any impact on development are determined primarily by responsible leadership, special staff assistance, accurate and reliable information, participatory budgeting and effective monitoring and control over the execution of the budget plan ( Meyers 1999, Bland 2008, Cheng et al 2007, Cheng 2007,He 2011,Zhu 2007, Wu et al 2011 2009). In the Nigerian context, the politics of who gets what is particularly important in shaping the budgeting system 
and indeed the extent to which it is accepted at all by the ruling elite. Effective budgeting is a sine qua-non for economic development of a country and also eradication of social ills.

As a result, in 2007, vision 20:2020 was unveiled by the government, declaring the intention of catapulting Nigeria into the group of twenty top economies by the year 2020.This was anchored in the seven point agenda of Yar'Adua/Goodluck administration with the objectives of meeting energy transportation, food security needs of Nigeria among others. The emergence of Goodluck Jonathan sets the background for a new order-search for a strategy for the recreation of Nigeria. This undoubtedly, necessitated the introduction of the transformation agenda. The cardinal element of the transformation agenda of the economy includes constitutional and electoral reforms and the transformation of the budgeting process. In 2011, barely twenty four hours after the minister of Finance, and coordinating minister of the economy blew the whistle alleging that some strange projects were miraculously sneaked into the 2011 budget; President Goodluck Jonathan had said that Nigeria is suffering from poor budgeting system. In addition, he said that the way we do budgeting does not really give the federal government enough funds to intervene (Jonathan, 2011).Ekeocha(2012) supported this view when he said that late submission of the budget to the National Assembly over the years has led to late commencement and thus poor budget implementation and its attendant consequences. The National Assembly has also frowned at the budgeting process to the point that the House of Representative in its legislative agenda resolved to get the fundamentals of the budget right. (Crook, 2003, Agu, 2003, Ugbene 2009, and Brune1993). The public and civil societies have adjudgesd the current federal budget weak and unable to transform the economy. Unfortunately, few studies on the subject matter did not contextually situate government budgeting in Nigeria, let alone consider a budgeting process in another country that could be employed to achieve the much needed economic transformation.

It is important to underscore that this paper drew its inspiration from the statement by the public, civil society and the president on the need to get the budget process right so as to achieve the much needed economic transformation. Therefore, a discussion on budgeting and economic transformation in Australia is both timely and pertinent. This is because on going through the literature, we discovered that Australia has enjoyed over sixteen years of continuous economic growth and this was attributed to her effective budgeting system. The challenges effectively addressing this issue require an elaborate and lengthy analysis, we will therefore, focus on three questions: What is the nature of Nigeria' and Australia's budgeting system? What is the justification for using Australia's budgeting system? Are there lessons to be learned from Australia budgeting system?

To respond to these questions, we first examine the nature of Nigeria and Australia budgeting systems. Secondly, we would examine Australia budgeting- system in relation to its impact on her economy and thirdly find out the lessons Nigeria could learn given that Nigeria's budgeting process needs to be transformed so as to impact positively on the economy.

\section{The Nigerian Budget Process.}

Budget Formulation Calendar: Key Stages \& Requirements in Annual Budget Cycle.

1. Medium-Term Revenue Framework 2 Medium-Term Fiscal Framework. 3 Medium-Term Sector Strategies

4. Formal MTEF/FSP Reports

5. Budget Presentation \& Appropriation.6 Budget Monitoring \& Evaluation.

In Nigeria, budget preparation is a shared responsibility of the Executive and Legislative arm of government. The Annual budget cycle starts in January in principle not in practice. Nigeria fiscal year starts in January.

Budget Planning/Formulation: The budget office of the Ministry of Finance developed the budget in accordance with the Federal Government fiscal policy. The budget office met early in the fiscal year with key revenue generating agencies including Federal Inland Revenue Services, Nigerian Custom Services, and the Nigeria National Petroleum Corporation as well as key economic agencies including NDC, NBC and CBN to assess and determine trends in revenue performance and macroeconomic indicators and the implication of such trends for the next three fiscal years (Ekeocha, 2012). This led to the preparation of medium term revenue framework (MTRF) which sets the tone for work on the budget. The MTRF helped to determine the projected revenue from various oil and non-oil sources. A meeting would be held with key agencies to agree on macroeconomic data and revenue agencies to finalize revenue forecasts and the initial bilateral discussions with parastatals and agencies of government of 3 years estimate of revenue. The outcome from MTRF would be fed in to the "medium term, fiscal expenditure framework (MTEF). MTEF was a fiscal framework which comprised indicative aggregate expenditure ceilings, projection of indicative fiscal balance and a deficit source of financing and aggregate level preparatory work on main components of expenditure (i.e. statutory transfer, debt service and expenditure).

The outcome of the MTEF led to "Medium Term Sector Strategies" (MTSS). Government has used the MTSS to prioritize and align the capital expenditure of large-spending MDA with the development objectives of the government (Ekeocha, 2012). 
Diogu and Ekeocha (2012) noted that the MTRF was further developed into a formal medium term expenditure framework "report" which includes the fiscal strategy paper and MDAs expenditure ceilings. This formal MTRF/fiscal strategy paper under the fiscal responsibility act was required to be presented to the Federal Executive Council and then to the National Assembly by the Minister for consideration and approval.

\section{Budget Call Circular and Preparation of the Executive Budget Proposal}

On approval of the MTRF fiscal strategy paper and MDA expenditure ceiling, the budget office under the supervision of Minister of Finance issued a "call circular". The aim of the call circular was to instruct the MDAs to allocate their capital expenditure ceilings across their existing new projects, programmes and other initiatives. In addition, the MDAs are required by law to submit estimates of their recurrent expenditure for personal costs and overhead. It was the duty of the budget office to evaluate and consolidate the submission of the various MDAs and prepare the draft budget. This process most times took place in August though timeframe was not strictly adhered to.

\section{Presidential Submission to the National Assembly}

The draft estimate is therefore presented to the president by the Minister of Finance for approval. Once the budget is approved, the president presents it together with other supporting documents to the National Assembly for consideration and appropriation, typically at a joint session of the Senate and the House of Representatives.

\section{Legislative Scrutiny and Approval}

In accordance with the legislative practice and procedures, the budget however would be considered separately by the House and Senate of the national Assembly. Subsequently, the drafts are harmonized by the two houses and recommendations of the various committees are considered and collated with the oversight of the MDAs. The harmonized estimate would be approved by each chamber of the National Assembly separately and then presented on Appropriation Bill to the President for assent. Once approved by the President, it becomes an Act of parliament passed into law. It is interesting to note that all the relevant committees in both houses review and recommend changes to various segments of the budget. However, there is usually "Horse Trading" between the executive and the legislature. It is worthy to note that the various parameters used in drafting the budget are debated and in some cases adjusted by the relevant committee especially the Finance, Appropriation, National Planning (NP) and legislative committee during their deliberation on the MTEF submitted by the executive to the National Assembly.( In some cases, a number of projects are included in Appropriation Act subsequent to submission of proposal by executive and this project has no engineering design and costing).Their decisions guide the general debate in the plenary who also adjusted other benchmarks such as the oil price benchmark, the production of crude oil and the size of funding for oil and gas production in the joint venture agreement as well as the level of debt repayments to be made in any fiscal year (Ekeocha 2012 and Okogu 2013). In some cases there would be large variance between executive proposals and Appropriation Bill approved by NASS and this created difficulty in ability to fund the budget.

\section{Budget Implementation}

The various Ministries, Department and Agencies of the Federal Government are involved in the implementation stage. The funds approved for capital expenditure are released during the first quarter to the relevant spending MDAs. It is interesting to note that the Federal Ministry of Finance instituted since 2005, a cash management committee to avoid non availability of cash for the smooth functioning of government budget. These measures however reduce discretionary borrowing from overdraft account of the Central Bank and avoid delays towards completing capital projects.

\section{Monitoring and Evaluation of the Federal Budget}

This is the final stage in the budget process - the oversight function which is carried out by the Ministry of Finance (MOF), the National Planning Commission (NPC), the National Assembly (NA), the National Economic Intelligence Agency (NEIA), the Presidential Monitoring Committee (PMC), the Office of the Auditor General of the Federation and the Accountant General of the Federation. These agencies carry out actual inspection of the capital projects in various capacities. The Ministry of Finance (MOF), NPC and NA are the most notable in this task through its think-tank - the Policy Analysis and Research Project (PARP) which is now National Institute for Legislative Studies (NILS).

\section{Australia Budget Process.}

Australian fiscal year starts on $1^{\text {st }}$ July. The budget formulation cycle begins ten months prior to start of the fiscal year. Australia based its budget on the Web minister model but with significant modifications. The 
most prominent features of the Australian system are the fact that party discipline is strong so the budget is usually passed essentially unchanged and the senate plays a more active role in reviewing the details of the budget than the House.(NDI,2003).

\section{Fiscal year: 1 July-30 June}

September -Cabinet submission and resulting budget circular.

October -The Prime Minister seeks proposals for new initiatives from ministers.

November- Senior Ministers' Review (SMR) /Strategic Budget Committee (SBC).

January-February Costing of new policy proposals.

March- Expenditure Review Committee (ERC).

April- Budget Cabinet.

April-May "Hunting license".

May- Budget submitted to Parliament.( Adopted from Blondal et al 2008)

\section{Budget Formulation Calendar: Fiscal Year 1 July - 30 June}

Submission by the Cabinet: This is the first step in the budgetary process. The Treasurer and the Minister for Finance provide a submission on the process and timetable for the forthcoming budget to the cabinet. On consideration of the submission by the cabinet, the Department of Finance issued a budget circular detailing the timetable for the forthcoming budget formulation process, the document was largely technical in nature, setting timeliness for the various milestones of the budget process and establishing threshold for the varying treatment of different proposals - such as what will be considered by the cabinet's Expenditure Review Committee (ERC) and what will be considered in the "minors" process. The budget circular is broadly similar from one year to another, although changes may be made following a "post mortem" evaluation of the previous year's process. The new government had streamlined the budget circular formally known as the "budget process operational rules" by introducing the "Finance Minister's Instruction" (FMIs). However, the budget circular does not outline any fiscal policy goals for the forthcoming budget and does not contain any assessment of the overall macroeconomic situation.

Strategic Budget Committee: In October, the Prime Minister traditionally writes to portfolio ministers requesting for their proposals for new initiatives. The prime minister does not indicate overall policy priorities because the new government has yet to determine how the new phases of the budget process will operate but a modified form of the previous year budget was used. Consequently, the various lobby groups and communities sent letters to their respective portfolio ministers. By late October, the budget proposals in conformity to a standard template for new policy proposals would be delivered to the Prime Minister.

Subsequently, officials from the three central agencies, namely the Department of Prime Minister and Cabinet (DPMC), the treasury, and the Department of Finance- referred to as the "trilateral review" will review the proposals before the vetting of the Senior Minister's Review (SMR) and the Strategic Budget Committee (SBC). The SMR/SBC comprise the Prime Minister, the Deputy Prime Minister, the Treasurer and the Minister of Finance. The views of the three central agencies on whether an individual submission should be approved for further development and the consideration of the ERC or rejected and not further developed would be offered. The Minister via formal cabinet minister received the notification of the approved proposal and the ones that could further be developed and subsequently submitted same to the ERC for consideration. The Minister could appeal; this would generally take the form of the Prime Minister allowing a minister to bring an amended new policy proposal for consideration by the ERC.

Expenditure Review Committee: The next step was the ERC. The respective "Portfolio Budget Submissions" document would be prepared by the portfolio minister after SMR/SBC inputs. These submissions are usually long background documents which contain the portfolio ministers "business case" for their proposals. One submission for portfolio was expected but more than one submission are made in reality as ministers, with the approval of senior ministers, may bring forward separate submissions for specific proposal to highlight them or for large and complex cross portfolio proposals. The submissions must contain costing of the proposals and the costing must be in agreement with the costing of the department of finance. This stage takes place in January and February. Disagreements may emerge on volume issues in relation to formula based programmes. However, more serious disagreements may occur at the operating costs in order to manage the respective programme, but, disagreement that was judged to be of a high political nature would be brought forward as an issue for the ERC.

The Department of Finance prepares "Green Brief" for each submission. The "Greens" summarized the proposals and brought together all available information as well as stating the perspective of Department of Finance on policy issues. Departments are able to see their respective Green before the relevant ERC meeting in order to prepare their own brief for their Ministers. The Minister of Finance may be lobbied by the Minister once they know of the Green's content. Sometimes, the Minister of Finance may disagree with the contents of a Green. 
Subsequently, the submissions are circulated officially to the three control agencies for comments and new policy proposals may be circulated to other agencies that are affected by the proposal.

In March, the ERC meets to decide on new proposals. An updated economic and financial outlook (based on existing policies) would be prepared by the treasury and the Department of Finance to guide the ERC. In addition, an overview Green submitted by the Department also provides the framework for the ERC discussion and subsequent decisions. The ERC will meet for about ten times over the four week period.

It is interesting to note that each Minister would make a case for his/her proposal. The prospective Ministers speak to their proposals and are then questioned by the committee members. Based on their response, the ERC forms an opinion on whether to support, reject, or send away the proposals for further work. Information regarding the financial implications across the forward estimates by the ERC would be provided to the Minister of Finance and Treasurer by the Department of Finance. The next stage is the Budget Cabinet.

\section{The Budget Cabinet}

In April, the decisions of the ERC are discussed by the three cabinets known as the "Budget Cabinet". Also the financial implications in aggregate are also disclosed to the Budget Cabinet by the National Security Committee. The cabinet does not endorse as the decision of the National Security Committee is final on this regard. Then the Ad Hoc Committee comes if necessary.

\section{The Ad Hoc Revenue Committee}

This committee met after the Budget Cabinet in late April to hear the latest economic assumptions and revenue estimate as discussed by the treasurer. The committee also decided on substantive taxation measures.

\section{"Hunting License"}

The aim of the committee was to involve senior ministers to decide on major tax cuts, tax expenditures and other"big ticket" expenditure items in the light of the latest surplus estimates. These initiatives are developed in close confidence and are often used as the main headlines of the budget. From April onwards, Ministries and Agencies work on the preparation of the relevant budget documentation. Their final drafts are submitted to the central agencies for approval.

The Department of Finance (DF) and the Treasury prepared the budget papers while line agencies prepared their portfolio budget statements.

The budget would then be presented simultaneously to both houses of parliament on budget night, traditionally, the second Tuesday in May.

Parliamentary Budget Cycle: The budget was usually introduced on the second Tuesday in May. The treasurer in presentation of the budget would highlight important points in the budget and provided commentary on government overall policy priorities. Generally, budget debate then commenced in plenary sessions in the House and lasts for about one week. The debates were mainly an overall political and economic debate rather than a debate on specific measures in the budget. However, the general debate continued in the main committee for another one week. The main committee was just a parallel plenary session designed to speed the work of the House by having two concurrent tracks for considerations of legislation.

Following this general budget debate, a vote would be taken to approve the second readings of the budget. This would be viewed as "a principal" approval of legislation before it would be considered in detail. By mid June, Senate committees scrutinized the budget proposal and their report carefully. This report alongside the budget would be presented to the House in Plenary session where the final approval would take place. The budget bills are then referred to the senate. The senate then approved the budget as proposed by the government except in exceptional circumstances.

By the end of June, the final stage in the legislative process was assented to the budget by the Governor General under the constitution, the Governor General may assent a bill or withhold assent but in practice, a bill passed by both Houses always received assent. The budget takes effect on 1st July.

\section{Justification For Using Australia For This Comparative Study}

Australia had a rich and long life of pioneering budget reforms. It was one of the countries that had paid down all her net debt and had established the future fund in order to fully finance all government employee future pension obligations (Commonwealth of Australia, 2012).

Australia had enjoyed an enviable economic and fiscal environment in recent years. In addition, in 2012 - 13 budgets, Australia returned the budget to surplus despite significant revenue losses since the global financial crisis (GFC).It is difficult to have a balanced budget :because people tend to increase their demand when they have a chance to reallocate but, in the case of Australia the reverse was the case (He, 2011, and Ma 2009). According to commonwealth of Australia report 2012, this is the best defense in uncertain times and allows monetary policy to respond to economic developments. The benefits of the boom were spread to families 
and business across Australia. This actually sends a clear sign of the strength of the Australia economy where many countries are still struggling to recover from the global financial crisis and recent global instability.

Furthermore, Australia had strong economic fundamentals, solid growth, and low unemployment record, and high levels of running investment. Therefore, the budget returning to surplus was appropriate. It was a clear sign of Australia economic strength and Australia was currently one of eight countries that met this standard. Returning to surplus sends a strong message of confidence to the rest of the world during a period of heightened global uncertainty. In addition, Australia was one of the world's strongest economies while many advanced countries are struggling to reach their pre-crisis level of output; the economy was significantly larger than it was before the GFC. Over seven hundred and fifty thousand jobs have been created in Australia since the end of 2007 while around twenty seven million jobs have been lost across the world over the same period.

Again, Australia had strong public finance, solid economic growth, low unemployment rate, contained inflation and very low level of public debt. Australian economic strength is the envy of the world. It is the strength of Australian public finance that was the key reason behind her receiving an AAA credit rating with a stable outlook from all the major rating agencies for the first time.

In advanced economies like United States, Japan, Euro and United Kingdom, Australia had a very high GDP level, low unemployment rate, lower inflation rate and was the first country to return to budget surplus faster. Returning to budget surplus had actually contributed to Australia's best defense at a time when the global economy is undergoing dramatic structural changes and the global outlook remains uncertain. However, Australia's budgeting process had various special features which actually were the secret behind the success recorded by Australia government in the recent past. These special features are; unique organizational arrangement including the strong role of cabinet committee, multiple central agencies and the limited role of spending ministries vis-à-vis their agencies. Fiscal rules based on principle rather than specific targets, rolling multi-year towards estimates that form the basis of the annual budget system

- The use of accrual budgeting and the use of outcome and output framework (Blondal et al, 2008). This was actually what endeared the authors to use Australia as a case study for Nigeria to learn from.

\section{Theoretical Framework.}

Scholars have tried to provide an understanding of the importance of budgeting in the development of the economy. The first of such theoretical orientation is the game theory. According to Neuman and Morgenstern (1944), game theory is a situation in which the interaction of many individually rationale decisionmaking processes - one process per person produces an outcome intended by no one. It could also be viewed as the study of the ways in which strategic interactions among economic agent produce outcome with respect to the preference (utilities) of those agents where the outcomes of the question might have been intended by none of the agents. Here, the players in the game are those parties involved in budget preparation, approval and implementation. The executive prepare the budget having considered the MTRF and MTEF and forward same to National Assembly after fulfilling the required processes concerning budget draft. The resources are limited while human wants are many. Therefore, the needs of the organization are ranked and selected according to priority and in line with the governments' fiscal policy. Utility refer to some ranking on specified scale. The budget office of ministry of finance which is player A develops the budget in accordance with the federal government fiscal policy with key revenue agencies as well as key economic agencies to assess and determine trends in revenue performance and macro-economic indicators and the implications of such trends led to the preparation of MTRF. The outcome of the MTRF fed into MTEF and the outcome of the MTEF fed to MTSS. This however led to budget call circular which was to allocate capital expenditure ceilings across the existing and new projects, programmes and other initiatives. This is where individual rational decision making process comes into play. The Legislature who should be considered player B in the game also in accordance with the legislative practices and procedures consider the budget. The House and Senate of the National Assembly who are also players in the game harmonized and considered the recommendation of the other players in the game. This eventually produced an outcome intended by none of the agents. All the various players in the game are playing to make an impact.

Section 3: Comparative Analysis of Australia and Nigeria GDP, inflation rate, employment level, debt, etc. A comparative analysis of Australia and Nigeria's Gross Domestic Product (GDP) is shown below.

Table 1: Gross Domestic Product, Constant Prices (Percent change)

\begin{tabular}{|l|l|l|}
\hline Years & Australia & Nigeria \\
\hline 2000 & 3.146 & 5.318 \\
\hline 2001 & 2.613 & 8.164 \\
\hline 2002 & 3.935 & 21.177 \\
\hline 2003 & 3.138 & 10.335 \\
\hline 2004 & 4.083 & 10.585 \\
\hline 2005 & 3.113 & 5.393 \\
\hline
\end{tabular}




\begin{tabular}{|l|l|l|}
\hline 2006 & 2.682 & 6.211 \\
\hline 2007 & 4.676 & 6.972 \\
\hline 2008 & 2.5 & 5.984 \\
\hline 2009 & 1.373 & 6.96 \\
\hline 2010 & 2.544 & 7.976 \\
\hline 2011 & 2.035 & 7.19 \\
\hline
\end{tabular}

Source; IMF, World Outlook, April 2012.

\section{Fig. 1: Gross Domestic Product, Constant Prices (Percent change)}

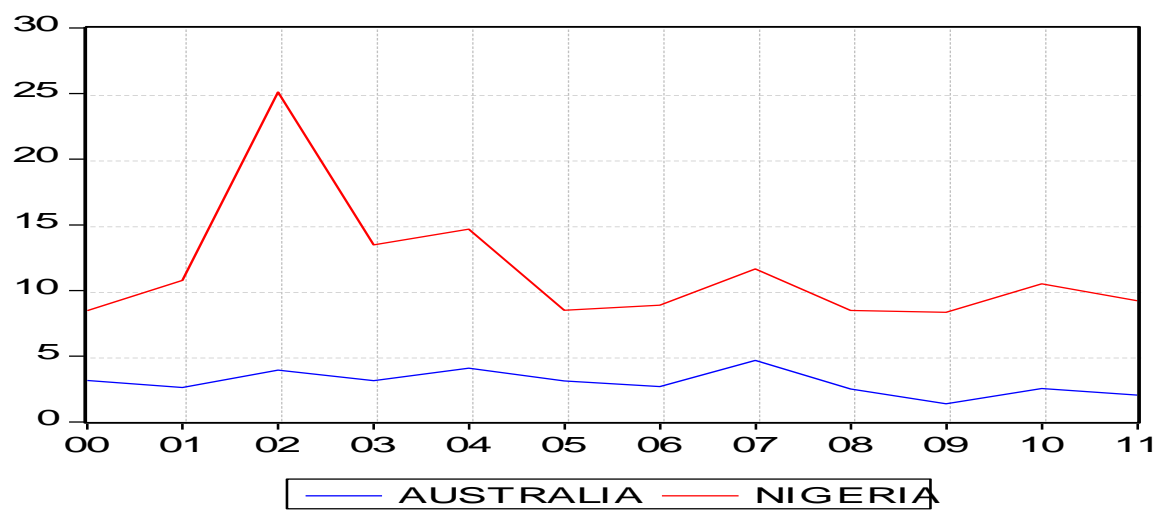

Annual percentages of constant price GDP are year-on-year changes; the base year is country-specific (IMF, World Outlook, April 2012). Expenditure-based GDP is total final expenditures at purchasers' prices (including the f.o.b. value of exports of goods and services), less the f.o.b. value of imports of goods and services (IMF, World Outlook, April 2012). Nigeria's GDP lies above the Australian's modest GDP growth rate at above 5\% with the highest rate at $21.177 \%$ in 2002. In 2007, Australian's GDP has its highest growth rate at 4.67\% just below 5\% and Nigeria recorded 6.972\% same year. Blöndal, Bergvall, Hawkesworth and DeightonSmith (2008) noted that Australia's outstanding economic performance is attributed to the structural reforms and prolonged boom in commodity market. Australia is a major commodity producer, including iron ore and metallurgical coal (both for steel), bauxite (for aluminum), thermal coal (for energy), uranium, lead, zinc, gold, silver, copper, crude oil and gas, and industrial diamonds whereas, Nigeria's major income earner is crude oil. In 2010 and 2011, Nigeria recorded 7.976\% and 7.719\% GDP growth rate respectively while Australia recorded $2.544 \%$ and $2.035 \%$ in 2010 and 2011 respectively. The modest Australia GDP growth rate is confirmed by the low annual inflation rate as shown in fig. 2 below.

Fig. 2: Annual Inflation Rate of Australia and Nigeria.

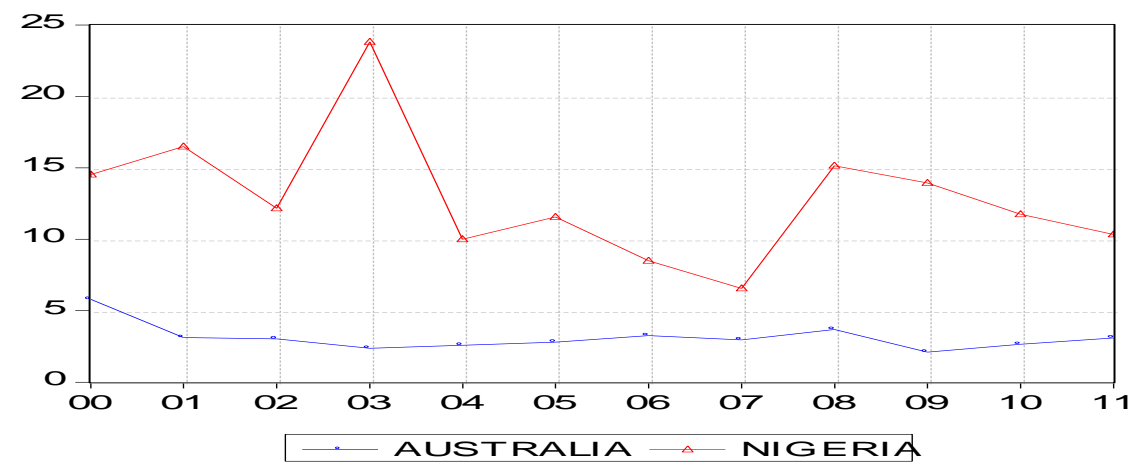

\begin{tabular}{|l|l|l|}
\hline \multicolumn{3}{|l|}{ Table 2: Annual Inflation Rate. } \\
\hline Years & Australia & Nigeria \\
\hline 2000 & 5.802 & 14.527 \\
\hline 2001 & 3.123 & 16.495 \\
\hline 2002 & 3.028 & 12.169 \\
\hline 2003 & 2.366 & 23.811 \\
\hline 2004 & 2.591 & 10.008 \\
\hline 2005 & 2.799 & 11.565 \\
\hline 2006 & 3.254 & 8.5 \\
\hline 2007 & 2.958 & 6.566 \\
\hline 2008 & 3.685 & 15.148 \\
\hline 2009 & 2.108 & 13.935 \\
\hline 2010 & 2.655 & 11.742 \\
\hline
\end{tabular}




\begin{tabular}{|l|l|l|}
\hline 2011 & 3.103 & 10.333 \\
\hline
\end{tabular}

Source. IMF, World Outlook, April 2012.

Inflation, end of period consumer prices (Percent change), annual percentages of end of period consumer prices are year-on-year changes (IMF, World Outlook, April 2012). Just like the GDP graphical representation above, Nigeria's inflation rate line lies above the Australian's inflation rate line. Nigeria achieved the lowest inflation rate in 2007 at $6.566 \%$ while recording the highest inflation rate of $23.811 \%$ in 2003 . After 2007, the inflation rate in Nigeria rose to $15.148 \%$ in 2008 and has been on the fall afterwards to close at $10.333 \%$ in 2011. Australia's inflation rate recorded the highest in the beginning of the period in 2000 at $5.802 \%$ and has been on the fall afterwards dropping to the lowest rate of $2.108 \%$ in 2009. In 2008, Australian's inflation rate rose to $3.685 \%$ from $2.958 \%$ recorded the previous year. At the end of the period 2001, Australia's inflation rate rose to $3.103 \%$. However, it is noteworthy that Australia's economy never recorded inflation rate as high as $5.802 \%$ recorded in 2000 throughout the period under review. However, with the inflation targeting introduced, Australia has maintained single digit inflation from 1990 - 2011. She has also maintained price stability and with stable price. It removes uncertainty and risk.

Table 3: Government Revenue as a Percentage of GDP

\begin{tabular}{|l|l|l|}
\hline Years & Australia & Nigeria \\
\hline 2000 & 36.423 & 42.12 \\
\hline 2001 & 35.629 & 45.786 \\
\hline 2002 & 35.384 & 32.946 \\
\hline 2003 & 36.203 & 31.967 \\
\hline 2004 & 36.373 & 35.356 \\
\hline 2005 & 36.577 & 36.298 \\
\hline 2006 & 36.472 & 32.287 \\
\hline 2007 & 35.529 & 26.9 \\
\hline 2008 & 33.691 & 32.019 \\
\hline 2009 & 33.469 & 17.813 \\
\hline 2010 & 32.002 & 23.266 \\
\hline 2011 & 32.329 & 30.149 \\
\hline
\end{tabular}

Source; IMF, World Outlook, April 2012.

Fig. 3: Government Revenue as a Percentage of GDP

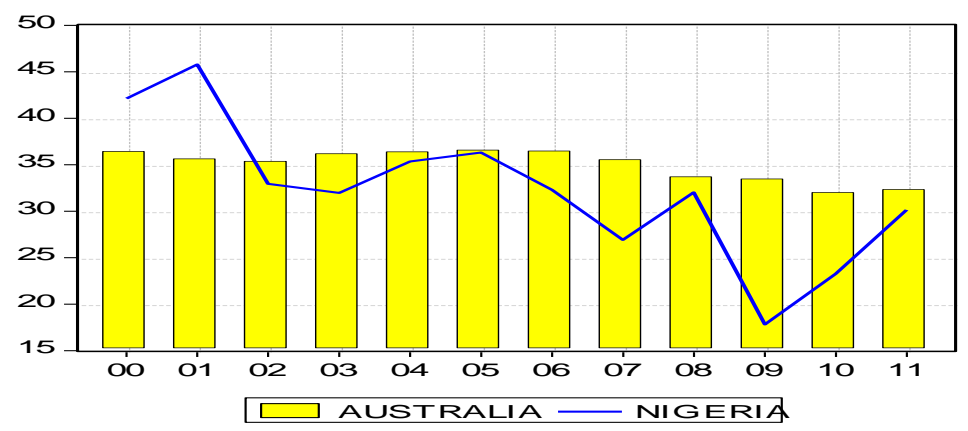

General government revenue (Percent of GDP), revenue consists of taxes, social contributions, grants receivable, and other revenue. Revenue increases government's net worth, which is the difference between its assets and liabilities. A look at the above table and figure 3 shows that Nigeria's Government revenue as a percentage of GDP has wide gyrations from an all-time high of $45.786 \%$ in 2001 to an all-time low of $17.813 \%$ in 2009 unlike that of the Australia that is stable and averaged about $33 \%$ all through the period under review. Hand in hand with Australia's overall economic performance, Australia's budget has been in surplus in the period under review with the exception in 2001/02 when a modest deficit was recorded; that moment coincided with a major tax reform in Australia (Blöndal, Bergvall, Hawkesworth and Deighton-Smith, 2008). On the other hand, Nigeria's budget has been on the deficit throughout the period under review as the overall budget balance has been below $0 \%$ as evidenced below: 
Fig. 4: Nigeria Budget Balance as a Percentage of GDP.

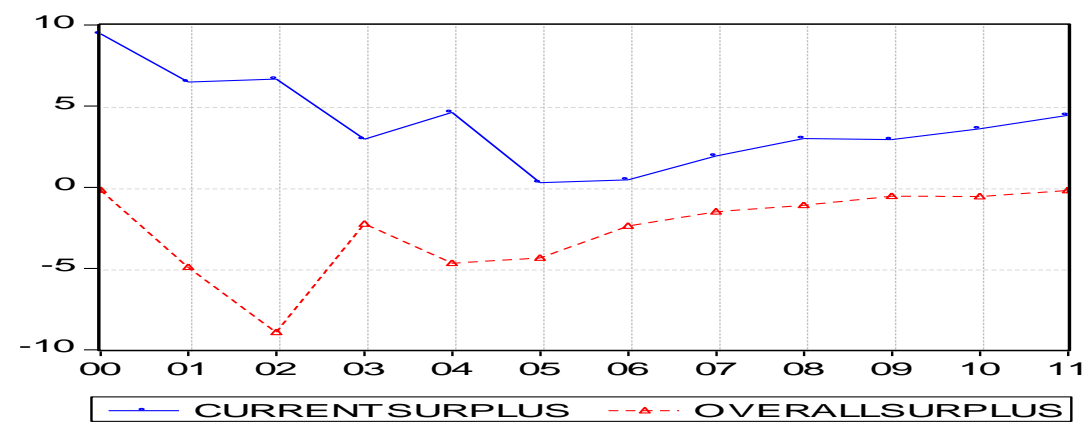

Table 4: Nigeria Budget Balance as a Percentage of GDP.

\begin{tabular}{|l|l|l|l|l|}
\hline Year & Current Surplus & \% of GDP & Overall Surplus & \% of GDP \\
\hline 1997 & $264,671.70$ & 9.45 & $5,000.00$ & -0.18 \\
\hline 1998 & $175,626.30$ & 6.48 & $133,389.30$ & -4.92 \\
\hline 1999 & $212,922.90$ & 6.67 & $-285,104.70$ & -8.93 \\
\hline 2000 & $135,673.60$ & 2.96 & $-103,777.30$ & -2.26 \\
\hline 2001 & $217,647.60$ & 4.61 & $-221,048.90$ & -4.68 \\
\hline 2002 & $19,976.50$ & 0.29 & $-301,401.60$ & -4.36 \\
\hline 2003 & $38,963.60$ & 0.46 & $-202,724.70$ & -2.39 \\
\hline 2004 & $220,800.00$ & 1.93 & $-172,601.30$ & -1.51 \\
\hline 2005 & $437,000.00$ & 3.00 & $-161,146.30$ & -1.11 \\
\hline 2006 & $546,403.10$ & 2.94 & $-101,397.50$ & -0.55 \\
\hline 2007 & $744,385.90$ & 3.60 & $-117,237.10$ & -0.57 \\
\hline 2008 & $1,076,077.50$ & 4.43 & $-47,378.50$ & -0.20 \\
\hline 2009 & $342,788.04$ & 1.38 & $-810,008.46$ & -3.27 \\
\hline 2010 & $-221,565.28$ & -0.76 & $-1,105,439.78$ & -3.80 \\
\hline
\end{tabular}

Source: CBN Statistical Bulletin, 2010.

Australia's receipts as a share of GDP have remained relatively stable in recent years, while payments have declined as a proportion of GDP. Due to the strong growth in Australia's GDP, especially in nominal terms, annual government receipts grew significantly in real and nominal terms over the period but, as a share of GDP, this growth was offset by very substantial income tax cuts (Blöndal, Bergvall, Hawkesworth and Deighton-Smith, 2008). Australia's payments also grew significantly but, for most of the period, growth in receipts outpaced the growth in payments. The development of Government expenditure as a percentage of GDP over the same period as shown in table 5 shows Nigeria has wide gyrations recording an all-time high above $51 \%$ in 2001 falling to $23.322 \%$ in 2005 and rising to $30.994 \%$ in 2010.

Table 5: General Government Expenditure as a Percentage of GDP

\begin{tabular}{|l|l|l|}
\hline Years & Australia & Nigeria \\
\hline 2000 & 34.685 & 36.176 \\
\hline 2001 & 34.765 & 51.124 \\
\hline 2002 & 34.379 & 30.812 \\
\hline 2003 & 34.571 & 35.307 \\
\hline 2004 & 34.299 & 27.212 \\
\hline 2005 & 34.137 & 23.322 \\
\hline 2006 & 34.635 & 23.345 \\
\hline 2007 & 34.244 & 25.299 \\
\hline 2008 & 34.487 & 25.709 \\
\hline 2009 & 37.579 & 27.207 \\
\hline 2010 & 36.773 & 30.994 \\
\hline 2011 & 36.598 & 29.069 \\
\hline
\end{tabular}


Source; IMF, World Outlook, April 2012.

Fig. 5: General Government Expenditure as a Percentage of GDP

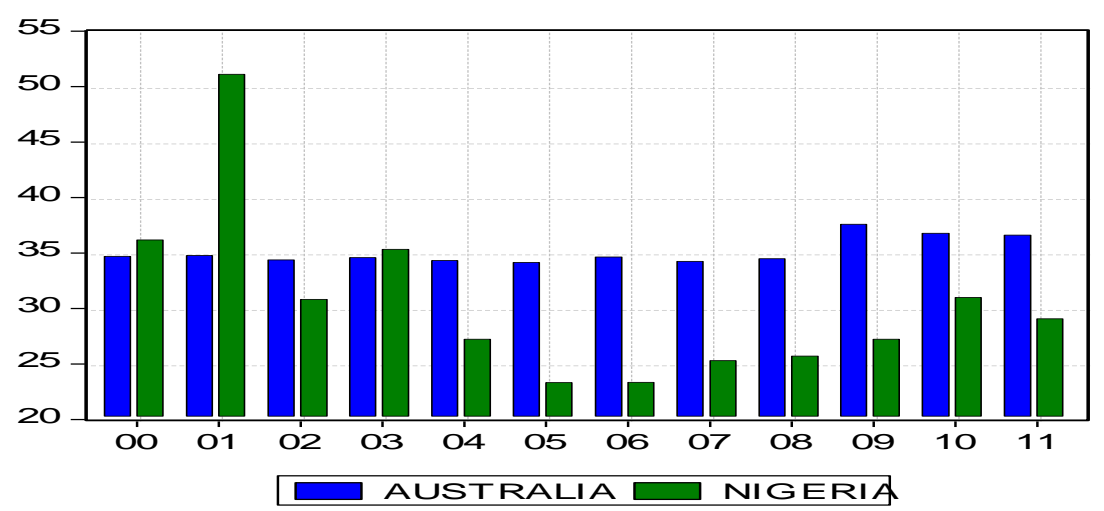

Blöndal, Bergvall, Hawkesworth and Deighton-Smith, (2008) noted that the Australian government used the budget surpluses and especially the proceeds of the sale of assets, including privatization of government business enterprises, to pay down debt. This translates to no debts from 2004 to 2009 (see Figure 5 and table 5) below. From the table 6, Nigeria has the highest net debt of $87.31 \%$ in 2001 though with a continuous reduction to $1.25 \%$ in 2008 . Nigeria huge borrowing could be traced down to the oil boom of 1971-1981 which introduced the era of big borrowing in Nigeria. Loans were acquired by various tiers of government as Nigeria embarked on major development and reconstruction projects in the wake of the civil war. The borrowing continued well into the civilian era, as the Federal Government embarked on the guaranteeing of many unviable loans taken by private banks, state governments and parastatals (DMO Office, 2005). In 1982, when oil prices crashed, Nigeria was unable to pay off the loans she borrowed and interest payments spiked, penalties rose, the crisis had begun (DMO Office, 2005). This pattern continued well into the military regimes of 1985-1993 and 1993-1998, when Nigeria stopped paying its debts to the Paris Club altogether, after the Paris Club refused to substantially reduce Nigeria's debt (DMO Office, 2005). With the return to civilian rule in 1999, Nigeria embarked on a relentless campaign for debt relief. This debt relief effort yielded fruit in June 29, 2005, when the Paris Club and Nigeria agreed on an US\$18 billion debt relief package (DMO Office, 2005). This resulted in the fall of Nigerian debt falling to $2.907 \%$ in 2006 see fig6 and table 6 below. However, the debt is on the increase once more hitting $16.695 \%$ in 2010 .

Fig. 6: General Government Net Debt.

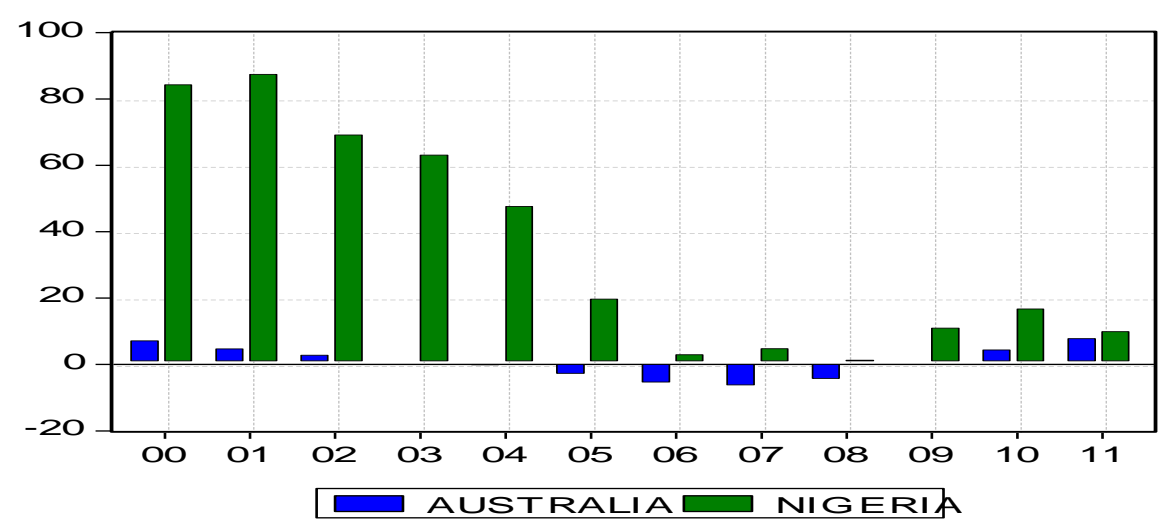

Table 6: General Government Net Debt.

\begin{tabular}{|l|l|l|}
\hline Years & Australia & Nigeria \\
\hline 2000 & 7.135 & 84.221 \\
\hline 2001 & 4.693 & 87.311 \\
\hline 2002 & 2.771 & 69.14 \\
\hline 2003 & 0.749 & 63.103 \\
\hline 2004 & -1.238 & 47.622 \\
\hline 2005 & -3.822 & 19.696 \\
\hline 2006 & -6.346 & 2.907 \\
\hline 2007 & -7.29 & 4.745 \\
\hline 2008 & -5.286 & 1.25 \\
\hline 2009 & -0.558 & 10.957 \\
\hline
\end{tabular}




\begin{tabular}{|l|l|l|}
\hline 2010 & 4.385 & 16.695 \\
\hline 2011 & 7.805 & 9.916 \\
\hline
\end{tabular}

Source. IMF, World Outlook, April 2012.

General government net debt (Percent of GDP), net debt is calculated as gross debt minus financial assets corresponding to debt instruments (IMF, World Outlook, 2012). These financial assets are: monetary gold and SDRs, currency and deposits, debt securities, loans, insurance, pension, and standardized guarantee schemes, and other accounts receivable (IMF, World Outlook, 2012).

The reduction in net government's debt in Australia was out of budget surpluses and modest government privatization. This reduction - and eventual elimination - of net debt created a virtuous impact on net interest payments, with the position turning to net receipts in 2007 and 2008 (Blöndal, Bergvall, Hawkesworth and Deighton-Smith, 2008). Nigeria's net debt reduction could be mostly attributed to the debt relief of 2005. This debt relief resulted in reduction of interest payment as a percentage of GDP from $8.75 \%$ (the highest percentage of interest payment to GDP during the period under review) in 2005 to $0.61 \%$ in 2006 as depicted below

Fig. 7: Nigeria's Interest Payment as a \% of GDP.

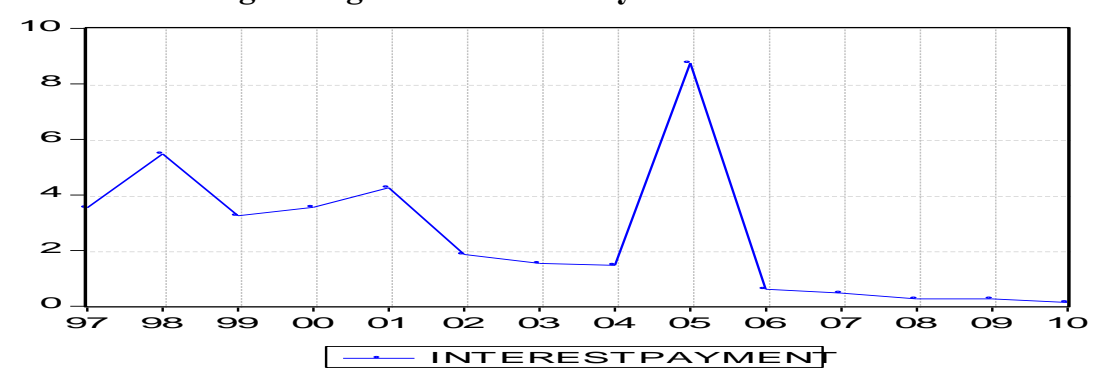

Table 7: Nigeria's Interest Payment as a \% of GDP.

Source, CBN Statistical Bulletin, 2011.

\begin{tabular}{|l|l|}
\hline 1997 & 3.54 \\
\hline 1998 & 5.48 \\
\hline 1999 & 3.25 \\
\hline 2000 & 3.56 \\
\hline 2001 & 4.26 \\
\hline 2002 & 1.86 \\
\hline 2003 & 1.54 \\
\hline 2004 & 1.47 \\
\hline 2005 & 8.75 \\
\hline 2006 & 0.61 \\
\hline 2007 & 0.47 \\
\hline 2008 & 0.26 \\
\hline 2009 & 0.26 \\
\hline 2010 & 0.13 \\
\hline
\end{tabular}
under review.

However, Nigeria recorded steady fall in interest payment from 2006 up to 2010, the end of the period

Fig. 8: Unemployment Rate for Nigeria and Australia. 


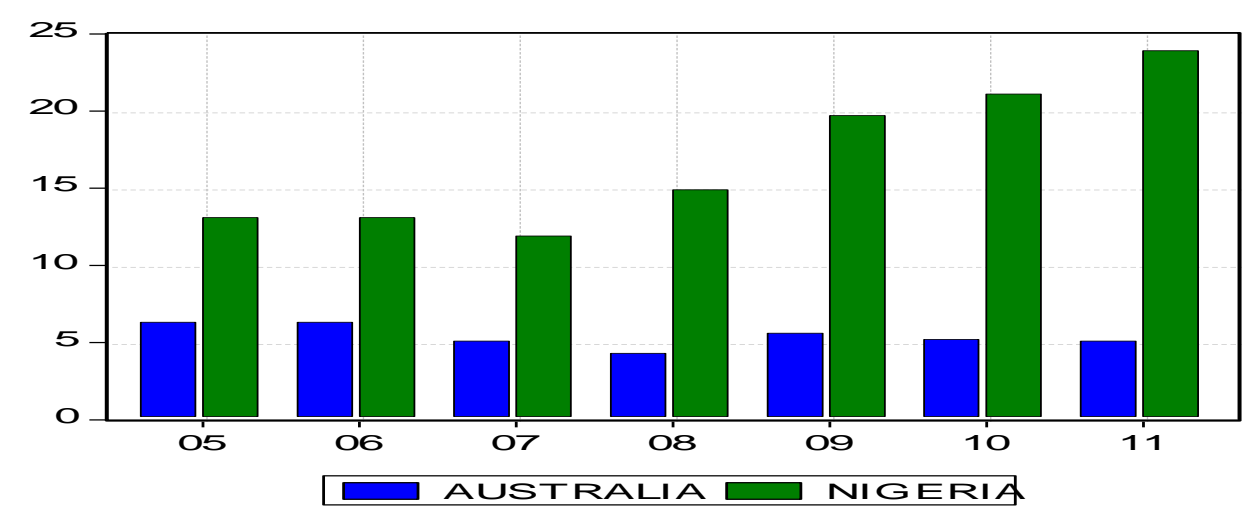

Table 8: Unemployment Rate in \%.

\begin{tabular}{|l|l|l|}
\hline Years & Australia & Nigeria \\
\hline 2005 & 6.300000 & 13.10000 \\
\hline 2006 & 6.300000 & 13.10000 \\
\hline 2007 & 5.100000 & 11.90000 \\
\hline 2008 & 4.300000 & 14.90000 \\
\hline 2009 & 5.600000 & 19.70000 \\
\hline 2010 & 5.200000 & 21.10000 \\
\hline & 5.100000 & 23.90000 \\
\hline 2011 & & \\
\hline
\end{tabular}

Source; IMF, World Outlook, April 2012.

The bold bar chart depicts the contrast in unemployment rate between Nigeria and Australia. Nigeria recorded a double digit, continuous rising unemployment rate hitting an all-time high rate of $23.90 \%$ in 2011 assuming the figures as furnished by Nigerian authorities are modest whereas that of Australia has been on the decrease and on an average of 5\% rate throughout the period under review. As a matter of fact, Australia had the highest unemployment rate of $6.3 \%$ in 2005 and 2006 while recording the lowest unemployment rate of $4.3 \%$ in 2008.

\section{Findings And Discussion}

Wide bodies of literature explored (Blondal et al, 2008, Commonwealth, 2012, He, 2011, Wen 2012, NDI 2003 etc) revealed that the institutional arrangement for budgeting in Australia was unique in many respects. The strong emphasis on cabinet committees, strong party discipline, active participation of the senate and the multiple central agencies involved in the budget formulation were hallmarks of budgeting in Australia. This fiscal arrangement however provided a solid and unified front for promoting fiscal discipline. Again, the respective roles of the Department of Finance and the Treasury including the greater role in budgeting for spending ministries within each portfolio vis-à-vis their agencies contributed in strengthening the budget process.

In addition, the forward estimates which was discovered to be the bedrock of Australia formulation process served to lengthen the time horizon in decision making, provided an agreed baseline which allowed budget discussions to concentrate on substantive decisions. The process was very impressive. Furthermore, Australia's extensive experience in reviewing the efficiency and effectiveness of existing programmes also contributed to effective budgeting in Australia.

The accrual budgeting system seemed to have failed the Australia government hence all decision making at budget formulation time and all deliberations in parliament continued to be on a cash basis. There is a total disconnect between the two.

However, the outcome and output framework have been discovered to serve as a catalyst for increasing the focus on results. The overall level of budget transparency and the disclosures required by the charter of budget honesty are exemplary according to Blondal et al. We also observed the strict compliance to time frame in the Australia budgeting process. Australia's fiscal year starts on 1st July and Australia government ensured that the budget was ready for implementation by the end of June. Australia's budget process was timely and pertinent.

In implementation of the budget, the organizational structure was also the hallmark of Budget implementation in Australia. Major changes were made in the structure in 1987 so as to achieve better policy 
coordination, administrative efficiencies and improved budget processes. The changes enhanced ministerial control of departments. Also, fundamental was the human resource management reform which occurs closely with the budgeting and financial management reform. The government of Australia also succeeded in reducing internal red tape as an attempt to address regulation inside government, the adoption of this approach however represented a bold step forward in ensuring that internal processes are based on systematic and rational analysis.

Very important was the development and implementation of appropriate performance monitoring and review mechanism for the programmes. This department ensured that programmes were supervised so as to meet the benchmark set by government.

The Nigeria budget process was confronted with many challenges which includes;

Determination of realistic assumptions and parameters underlying MTRF and MTEF in particular, oil price benchmark, oil production, exchange rate, Gross Domestic Product(GDP) growth and inflation rate and weak reporting culture by MDAs: this is an on-going project, a stage of implementation etc. Unplanned expenditure in particular, recurrent on the size and composition of the budget.

- Inability to release funds due to shortfalls in realising financing items despite high oil revenues

- Poor project planning and implementation

According to okogu 2012, large variance between executive proposal and appropriation bill approved by National Assembly had created difficulty in funding projects and had actually led to delays in commencement of implementation. We should also underscore the fact that projects which had no engineering design and costing were included in the Appropriation Act subsequent to submission of proposals by executive. We also observed that the capacity of the MDAs to utilize funds released was a severe constraint on ability to scale up capital utilization levels (Okogu, 2012).

Again, a close examination of the constitutional mandates for the executive with respect to the budget process revealed that the constitution was silent about the time frame upon which the executive will submit the proposal to the National Assembly. Section 81 of the constitution was too loose in aggravating the problem of poor budget implementation arising from delay in presentation of the budget to the National Assembly. Timeliness as a criterion for good budget implementation has always been observed in the breach of Nigeria.

Based on the forgoing, Australia's budget process is worthy of emulation by the Nigerian government for us to achieve the transformation agenda.

We therefore recommend for strong emphasis on the cabinet committees, which comprised the executive, legislative and the administrative. The duties of each of these agencies should be clearly spelt out and the executive needs to work closely with the legislature to ensure implementation of the approved budget. This would also help to reduce inclusion of projects without costing and engineering design subsequent to executive submission.

It is worthy to note that Australia's economic performance was attributed to two principal factors - the structural reforms and the prolonged boom in commodity demand and prices. A close examination of literature revealed that Nigeria's over dependence on oil has led the country to poor budget implementation as most of the resources on oil revenue are not realized. Nigeria should therefore diversify revenue sources to reduce over dependence on revenue from oil. Agriculture used to be the mainstay of the economy before the discovery of oil but had been relegated to the background. We earnestly advocate for resuscitation of agricultural products.

Again, the outcome and output framework which were discovered to be the hallmark of budgeting in Australia should be introduced in Nigeria as it was the catalyst for increasing the focus on results. This should contribute in no small measure to overall level of budget, transparency and disclosure.

The Australian government set timeliness for the various milestones of the budget process and established thresholds for the various treatments of different proposals. This is commendable and may have contributed to proper implementation of the budget process which has earned Australia strong economic fundamentals, solid growth, low level of employment, unemployment record, levels of mining etc. However, the constitution of the Federal Republic of Nigeria (FRN) was silent regarding timeframe upon which the executive will submit the budget proposals to the National Assembly. This has impacted negatively on the budget process as the budget does not start on 1st January in most cases. Nigerian government should adopt this time therapy for it was found to be a good therapy for improving budget process.

Interestingly, each minister would make case for his/her particular proposals. The prospective ministers speak to their proposals and are then questioned by the committee members and based on the questions and responses, the ERC forms an opinion on whether to support, reject or discard such proposal. This forum provides avenue for each minister to defend his/her budget. Nigerian government should also emulate this style of presentation and form of opinion.

In Australia, the hunting license's main objective was to involve senior ministers to decide on major tax cuts, tax expenditure items in the light of latest surplus estimate. However, in Nigeria, we have never returned the budget to surplus but to deficit. Therefore, Nigeria should include in our constitution the "hunting 
license" but their main objective should be to decide on major tax increases and other budget so as to ensure that we have a balanced budget rather than a deficit budget.

. The "Charter of Budget Honesty Act 1998" was deliberately introduced to help entrench sound and transparent fiscal policies and make it difficult for future government to deviate from it. This is commendable and should be adopted by Nigerian government. Again, the government of Australia has continued to use skilled personnel in budget preparation and implementation and she is committed to her duties. In Nigeria, the reverse is the case; most of the sensitive positions were given to party loyalist. For instance, during the previous regime, Prof.Dora Akunyelu who read Pharmacy was made the Minister of Information. What does she know about Mass Communication? This actually made her redundant throughout her tenure. It is the position of this study that if qualified persons are employed in budget preparation, approval and implementation, the end result would be effective and efficient budgeting process. We also advocate for strong party discipline and active participation of the senate which would help to promote budget process in Nigeria.

Conclusion

Nigeria has suffered from poor budget process for ages and this has impacted negatively on the economy. Transforming the budget process poses great challenges. Chief among them being corruption, Nigeria environment, negative attitude of the leaders and the led. These challenges pose great threats to the country's economic' transformation and increases its vulnerability to poor budget implementation. Therefore transforming the budget process requires seeing the crises as an opportunity which should be seized to address the country's budgetary process. It requires going beyond the crises to learn lessons from other successful countries preferably Australia; implement a structural transformation strategy; reform the Nigerian environment, tackle corruption head on and create the condition for solid budget process.

\section{Acknowledgement}

We acknowledge Blondal J.R, Bergavil D, Hawkesworth I. and Deighton-Smith R. We made extensive use of their work on Budgeting in Australia published by $\operatorname{OECD(2008)~in~this~study~and~Bright~Okogu,2012~}$

\section{References}

[1]. Agbakoba, J.A 2012, Developing Appropriate Administrative Instruments for the African Cultural Environment . Unpublished lecture material.

[2]. Abba, U. 2007,' Public Finance and Government Budgeting in Nigeria'. Abbot Books Ltd.

[3]. Ademola,A 2012 ' Budget Experts Worry about Budget Implementation. Punch 11 October,

[4]. Bland, F. A. (2008). Budgets: Budgetary Methods. Australian Journal of Public Administration. DOI: 10. $9111 /$ j.1467 - 8500. 1942 tb02005x.

[5]. Agu, S 2000 'Budgeting as an instrument of Public Accountability

[6]. Agu, S 2003' Budgeting and Financial Management' Unpublished Lecture Note.

[7]. Blandal, R., Bergvall, D. and Deghlan Smith, R. 2008, ' Budgeting in Australia'. OECD Journal on Budgeting. Vol. 8, ISBN 1608 7143.

[8]. Benoît Pierre Freyens 2010, ‘ Managing skill shortages in the Australian Public Sector:

[9]. Issues and Perspectives', Asia Pacific Journal of Human Resources 48(3) 262-286

[10]. Blöndal, J. R., Bergvall, D., Hawkeswogrth, I. and Deighton-Smith, R. 2008. "Budgeting in Australia" OECD Journal on Budgeting Volume 8 - No. 2.

[11]. Bram, S. Miekatrion, S. and Geert, B 2005, 'Lesson from Australia and British Reforms' in Results-Oriented Financial Management. OECD Journal on Budgeting Vol. 5, No. 2.

[12]. Brethon, A. and Wintrobe, R.1975, 'The Equilibrium Size of a Budget - Maximizing Bureau. Journal of Political Economy, 83: 195 $-207$.

[13]. Brunce, P, Robin, F. and LIonell, W.(1995). Advanced Budgeting: A Journey to Advanced management System” Management Accounting Research, 613, 253 - 265.

[14]. Budget Overview 2012, Common Wealth of Australia. ISBN978-0-642-74806-5 The Treasury.

[15]. Central Bank of Nigeria (CBN) (2011) Statistical Bulletin. A Publication of the Central Bank of Nigeria.

[16]. Cheng, J. 2007, 'Theory and Practice of Participatory Budgeting'. Comparative Economic and Social Systems (2): 52 - 57.

[17]. Cheng, J. and Chen Y. 2007, 'Participatory Budgeting in Local Governance: A Case Study of Xinhe Town, Zhenjiang province. Journal of Public management 4(3): $76-833$.

[18]. Curt, J. 2008, 'Programme Budgeting - Panacea or Mirage'. Australia Journal of Public Administration: Articles First Published on Line: $18^{\text {th }}$ march 2008, DOI: 10.1111/j. $1467-8500$. 1974. Tb 00801.x.

[19]. Debt Management Office (DMO) (2005) “Nigeria's Debt Relief Deal with the Paris Club" www.dmo.gov.ng. developmental stages.

[20]. Dirk-Jan K, Valentine, K, Barbara, D. and Ragnar, O. (2012). Budgeting in Montenegro.OECD Journal on Budgeting. Vol. 12: 1.

[21]. Ekeocha, P.2012,'An Analysis of the Federal Budgeting Process in Nigeria: Implications for Institutional Reforms for AchievingTimeliness'. International Institute for Science Technology and Education(IISTE) 2(6)ISSN2225-0565

[22]. Goodluck, J. 2011,'Nigeria has poor budgeting System' Leadership Newspaper Tuesday 13 September.

[23]. Groenewegen, P. D. 2008, "The Australia Budgetary Process" Australian Journal of Public Administration, DOI:10.IIII/j.14678500. 1973.tb00784.X

[24]. Harvey, G.2006,'Effective Budget Management; Take a Fresh Look at Your Workforce. Government Finance Review Pp 35-40

[25]. Hatry, H. P. and Blair I. H. 1976, 'Citizen Surveys for Local Government: A Copout Manipulative Tool or a Policy Guidance and Analysis Aid: in T. N. Clark (ed.) Citizen Preference and Urban Public Policy. Beverly Flies, CA: Sage: 129 - 139.

[26]. He B. G. 2011'Civic Engagement through Participatory Budgeting in China'. Three Different Logistics at Work. Public. Administration and Development 31:22-133. 
[27]. International Monetary Fund (IMF) 2012 "World Economic Outlook Database" http://www.imf.org/external/pubs/ft/weo/2012/01/index.htm.

[28]. Jones, L. R. and Jerry M. 1998. Federal Financial management "Navy Comptroller, 313": 42 - 48.

[29]. Kelly, I. and Sundell, D. 2009.'A Multiple Indicator Approach to Municipal Service Evaluation Correlating Performance Measurement and Citizen Satisfaction Across Jurisdiction'. Public Administration Review 62(5): 610 - 621.

[30]. King, C. S. Feltey, K. M. and Susel, O. N.1998.' The Question of Participation Toward Authentic Public Participation in Public Administration'. Public Administration Review 58(4): 317 - 326.

[31]. Kluvers, R. 2001 'Program Budgeting and Accountability in Local Government'. Australia Journal of Public Administration. Volume 60: Issues 2, $35-43$.

[32]. Kutt, J. 2008.' Programme Budgeting - Panacea or Mirage'? Australian Journal of Public Administration. DOI:10.111j 1467 - 8500 197413 1080. Or Vol. 33(4) $24-35$.

[33]. Legislature and the Budget Process, 2003 'National Democratic Institute for International Affairs.

[34]. Ma,J. 2009'The Dilemma of developing Financial Accountability Without Election. A Study of China's Recent Budget Reforms'. The Australian Journal of Public Administration 68(S1): S62-S72.

[35]. Marc, R. 1996. 'The case Against Balanced Budgets'. Australian Journal of Public Administration. Vol. 55. Issue 1 pg. 48 - 62.

[36]. Marc, R. 2010, 'Financial Control in Australia Government budgeting'. Research project in Accrual output Budget in Australian.

[37]. Marc, R. 2000, 'Contract Budgeting” Public Administration 78(1), 75-90.

[38]. Mascarenhas, R. "Searching for Efficiency in the Public Sector: Interim Evaluation of Performance Budgeting on New Zealand "Public Budgeting and Finance 16/3,: 13 - 27.

[39]. Mitton, C. and Donaldson, C. (2001). Health Care Priority Setting: Principle, Practice and Challenges. Australian Journal of Public Administration. Vol. 60(2) $44-59$

[40]. Nai-Ling Kuo (2012). Citizen Dissatisfaction Leads to Budget Acts on November: A Case Study of a Local Taiwanese Government. Australian Journal of Public Administration, Vol. 71 (Issue $2: 159-166$ ).

[41]. Niu, M.. (2010). Accountability Building through Budgetary Reform: China's Experience in Charles E. Manifedd (ed). Comparative Public Budgeting: A Global Perspective. Sudbury, MA. Jones and Bartlett Publishers, $43-53$.

[42]. Nnadozie,E 2012'Managing the Nigeria Economy in an Era of Global Financial Crisis. Lecture Presented at the 2012 Annual Public Lecture of the Nigeria Economic Society (NES) Transcorp, Hilton Abuja.18 March 2012.

[43]. Nigeria in Transformation, 2012, Office of The Secretary to the Government of the Federation.

[44]. Okogu, B,. 2011 “The Budgeting Process: Roles,Responsibilities, and Challenges'. Paper Presented to the Members of National Assembly Abuja on $8^{\text {th }}$ June 2011 .

[45]. Okogu, B 2011' Strategies for Effective and Efficient Budgeting Process and Implementation in Nigeria. Budget Office of the Federation.

[46]. Okolo, E. 2012 'Nigeria, and Budget Implementation’ Business Day

[47]. Participatory Budgeting Unit (2009). Participatory Budgeting: Values, Principles and

[48]. Rubin, I. S. 1990, 'Budget Theory and Budget Practice': How Good the ...? Public Administration Review 50(2): 179 - 198. CrossRef. Web of Science@ Times cited: 12.

[49]. Schater, H. L. 1997, 'Reviewing Government or Rein sating Ourselves?: The Role of Citizen Owners in Making a Better Government. Albany, N. 4. State University of New York Press.

[50]. Scheers, B. Sterck, M. and Bouchaat, G. 2005, 'Lesson from Australia and British Reforms in Results Oriented Financial Management'. OECD Journal vol. 5(2). ISSN 1608-7143.

[51]. Su, T. T. (2007, 'Public Budgeting Reform in Taiwan in G. E. Caiden and T. T. Su (eds.) The Repositioning of Public Governance: Global Experience and Challenges. Taipei: Best Wise: 321 - 345.

[52]. Thomas, J. C. 1995 'Public Participation in Public Decision. San Francisco: Jossey Bass.

[53]. Wildavsky, A. B. 1984, The Politics of the Budgetary Process. Boston: Little Brown.

[54]. Wilson, L. A. 1983, Preference Revelation and Public Policy Making Sense of Citizen Survey Data: Public Administration Review 43(4): $335-342$. .

[55]. Wu, Y. and W. Wang. 2011 “The Nationalisation of Public Budgeting in China: A Reflection on Participatory Budgeting in Wuxi'. Public Finance and Management Vol.(3): 262 - 283.

[56]. Yan Wu Wen Lalay, 2012 'Does Participatory Budget Improve the Legitimacy of the Local Government: A Comparative Case Study of Two Cities in China'. Australia Journal of Public Administration. Vol. 2: 122 - 135.

[57]. Zhu, S. 2007, "Realisation of Public Budgeting Efficiency: A Positive Research into the Participatory Budgeting in Zeguo. Journal of Guangdong Institute of Public Administration 19(6): 88 - 90. 